\title{
Wnt Pathway Regulation of Embryonic Stem Cell Self-Renewal
}

\author{
Bradley J. Merrill \\ Department of Biochemistry and Molecular Genetics, University of Illinois at Chicago, Chicago, Illinois 60607 \\ Correspondence: merrillb@uic.edu
}

Embryonic stem cells (ESCs) can generate all of the cell types found in the adult organism. Remarkably, they retain this ability even after many cell divisions in vitro, as long as the culture conditions prevent differentiation of the cells. Wnt signaling and $\beta$-catenin have been shown to cause strong effects on ESCs both in terms of stimulating the expansion of stem cells and stimulating differentiation toward lineage committed cell types. The varied effects of Wnt signaling in ESCs, alongside the sometimes unconventional mechanisms underlying the effects, have generated a fair amount of controversy and intrigue regarding the role of Wnt signaling in pluripotent stem cells. Insights into the mechanisms of Wnt function in stem cells can be gained by examination of the causes for seemingly opposing effects of Wnt signaling on self-renewal versus differentiation.

Eor a single-cell embryo to eventually form an F adult organism of trillions of cells, some cells in the early mammalian embryo must be able to generate all cell lineages in the animal. The potential to make all adult cell types defines the property of pluripotency, and it is maintained in proliferating cells through a process called self-renewal. As cells become specified to contribute to particular lineages, they typically lose the ability to make cell types from distinct lineages (Waddington 1957; Hochedlinger and Plath 2009). As such, pluripotency is lost during the initial steps of lineage commitment that occur during gastrulation (Beddington 1982, 1983; Lawson and Pedersen 1987; Lawson et al. 1991), which is a process that coordinates the generation of adult cell lineages with the elaboration of a basic three-dimensional body structure (Heisenberg and Solnica-Kre- zel 2008). In the mouse, pluripotency can be tested with various experiments; the gold standard is the injection of cells into a blastocyststaged embryo followed by contribution to a diversity of cell types in the chimeric animal or chimeric embryo after gastrulation. Cells are typically considered to have been pluripotent only if they contributed to all three germ layers (endoderm, mesoderm, and ectoderm).

Embryonic stem cells (ESCs) are generated in vitro by outgrowths from a preimplantationstaged embryo, frequently a blastocyst. Pluripotent cells from the inner cell mass (ICM) of the blastocyst proliferate to form colonies, which can be expanded into ESC cultures. When culture conditions for in vitro propagation of mouse ESCs (mESCs) were first discovered more than 30 years ago (Evans and Kaufman 1981; Martin 1981), the critical achievement was finding

Editors: Roel Nusse, Xi He, and Renee van Amerongen

Additional Perspectives on Wnt Signaling available at www.cshperspectives.org

Copyright (C) 2012 Cold Spring Harbor Laboratory Press; all rights reserved; doi: 10.1101/cshperspect.a007971

Cite this article as Cold Spring Harb Perspect Biol 2012;4:a007971 


\section{B.J. Merrill}

conditions supporting indefinite ESC self-renewal, that is, maintenance of pluripotency following cell division. Compared with the other cell systems discussed below in this article, mESCs ostensibly display the greatest capacity for self-renewal and the highest ability to maintain pluripotency. As such, mESCs are typically thought to represent a primitive, or "naive," cellular state in the early embryo.

Several culture conditions can support selfrenewal of mESCs. Initially, ESCs were grown in serum containing media atop a layer of mitotically inactivated fibroblasts, called feeder cells (Evans and Kaufman 1981). Feeder cells secrete the LIF cytokine, which binds a transmembrane receptor complex consisting of LIFR and gp130 proteins (Gearing et al. 1991; Gearing and Bruce 1992; Davis et al. 1993). LIF binding activates Jak/Stat signaling and Stat3 phosphorylation, which promotes ESC self-renewal (Niwa et al. 1998; Matsuda et al. 1999). Convincing proof of LIF's importance for self-renewal in vitro was shown when recombinant LIF protein was shown to be sufficient to replace feeder cells in ESC cultures (Smith et al. 1988; Williams et al. 1988; Nichols et al. 1990).

Essentially the same feeder cells can be used for both mESCs and human ESCs (hESCs); however, discrete activities of the feeders in terms of the cytokines they release are needed to effect optimal self-renewal for each cell. The LIF cytokine important for mESC self-renewal did not stimulate hESC self-renewal (Thomson et al. 1998). Instead, ERK signaling downstream from Fgf2 must accompany a feeder layer in serum-containing media for optimal hESC self-renewal (Xu et al. 2005). Interestingly, recombinant Fgf2 by itself could not replace feeders, and Fgf2 has been suggested to work in part by stimulating feeders to produce Activin/Nodal ligands; the combination of Fgf 2 and Nodal/ Activin is sufficient to support hESC self-renewal in serum-free chemically defined culture conditions (Vallier et al. 2004, 2009; James et al. 2005).

Clear differences exist between mESCs and hESCs. The colonies adopt different morphologies, they require distinct culture conditions for self-renewal, and they have significantly different gene expression signatures (Table 1). These differences make it interesting to compare hESCs with a different type of pluripotent mouse stem cell, called EpiSCs (for epiblast stem cells) (Brons et al. 2007; Tesar et al. 2007). Mouse EpiSCs are made from the epiblast of postimplantation-staged embryos between embryonic days 5.5 (E5.5) and E6.5 of embryogenesis (Brons et al. 2007; Tesar et al. 2007; Han et al.

Table 1. Pluripotent stem cell states: Naive and primed

\begin{tabular}{|c|c|c|c|}
\hline & Mouse ESC & Human ESC & Mouse EpiSC \\
\hline \multicolumn{4}{|l|}{ Effects of culture conditions } \\
\hline Serum + Lif & Self-renewal & Differentiation & Differentiation \\
\hline Wnt3a/GSK3inhibitor & Self-renewal & Differentiation & Differentiation \\
\hline Fgf $2+$ Activin A & EpiSC & Self-renewal & Self-renewal \\
\hline \multicolumn{4}{|l|}{ Gene expression profiles } \\
\hline Oct4, Sox2, Nanog & High & High & High \\
\hline Sox17, Eomes, Fgf5 & Low & High & High \\
\hline Klf4, Rex1, Stella & High & Low & Low \\
\hline \multicolumn{4}{|l|}{ Activity in pluripotency tests } \\
\hline Embryoid body & Pass & Pass & Pass \\
\hline Teratoma formation & Pass & Pass & Pass \\
\hline Blastocyst injection & Pass & Not determined & Poor \\
\hline Tetraploid complementation & Pass & Not determined & Not determined \\
\hline Epigenetic state & Naive & Primed & Primed \\
\hline
\end{tabular}

Three pluripotent cell systems are compared with respect to characteristics that describe their epigenetic state of pluripotency. See text for details. 
2010). Lineage specification of pluripotent epiblast cells begins soon after formation of a cup-like structure, and at E6.5, the cells in the epiblast begin to be specified to primary cell lineages during gastrulation. The in vivo cellular environment for ICM cells and postimplantation epiblast cells is considerably different, and it is not surprising that EpiSCs and mESCs display many different characteristics ( $\mathrm{Xu}$ et al. 2010). However, it was somewhat surprising that EpiSCs share many characteristics with hESCs, including a common colony morphology, Fgf2 + Activin A culture conditions, and gene expression signatures (Table 1) (Brons et al. 2007; Tesar et al. 2007). Like mESCs and hESCs, EpiSCs pass pluripotency tests for in vitro differentiation and teratoma formation. Whereas mESC can efficiently convert (i.e., differentiate) into EpiSC-like cells when switched to Fgf2/ Activin A media (Hanna et al. 2009; Greber et al. 2010), EpiSCs required genetic manipulation or reprogramming for efficient conversion to mES-like cells (Guo et al. 2009; Hanna et al. 2009; Greber et al. 2010; Guo and Smith 2010). Many investigators consider hESCs and mouse EpiSCs to be primed for differentiation as they reside in a less primitive differentiation state relative to the naive state of pluripotency in mESCs.

\section{INTRINSIC TRANSCRIPTION FACTOR NETWORKS SUPPORT PLURIPOTENT CELL SELF-RENEWAL}

All pluripotent cells are thought to use essentially the same core set of transcription factors in a conserved self-renewal network. Several reviews cover the topic comprehensively ( $\mathrm{Ng}$ and Surani 2011; Young 2011), and here I cover only the highlights important for understanding the role of Wnt signaling in pluripotent cells. Three transcription factors-Oct4 (also called Pou5f1), Sox2, and Nanog-are considered to constitute a core self-renewal network for several reasons. Each is genetically necessary for self-renewal of pluripotent cells when the ICM cells divide rapidly and give rise to the epiblast (Nichols et al. 1998; Avilion et al. 2003; Mitsui et al. 2003). Gene ablation and RNAi-knock- down experiments showed that Oct4 and Sox 2 are absolutely necessary for mESC self-renewal (Niwa et al. 2000; Avilion et al. 2003). $\mathrm{Nanog}^{-/-}$ESCs can be propagated in vitro, albeit at a reduced efficiency relative to wildtype mESCs (Chambers et al. 2007). Importantly, overexpression of Nanog has a potent and unique ability to prevent $\mathrm{mESC}$ differentiation (Chambers et al. 2003; Mitsui et al. 2003). Genome-wide chromatin immunoprecipitation (ChIP) experiments showed that Nanog, Oct4, and Sox2 all bind to a highly overlapping set of downstream target genes in each mESC and hESC (Boyer et al. 2005; Loh et al. 2006; Chen et al. 2008; Cole et al. 2008; Kim et al. 2008; Marson et al. 2008); notably, each protein occupied one another's gene regulatory region. RNAi knockdown of each Oct4, Sox2, or Nanog each caused largely overlapping effects on gene expression, consistent with each gene product regulating a common set of target genes (Loh et al. 2006). Many genes regulated by Oct4, Sox2, and Nanog include factors that play a downstream, yet important role in self-renewal, including Klf4, c-myc, Esrrb, Tbx3, and Nr5a2 (Gu et al. 2005; Ivanova et al. 2006; Jiang et al. 2008; Kim et al. 2008; Hall et al. 2009; Wagner et al. 2010). Together, these data are consistent with Oct4, Sox2, and Nanog being the central components of a feed-forward network of transcription factors that drives self-renewal of pluripotent cells (see Fig. 1).

\section{EFFECTS OF WNTs ON PLURIPOTENT CELLS}

\section{Wnt/ $\beta$-Catenin Signaling Inhibits}

Differentiation of Naive mESCs

For decades, mESCs indirectly contributed greatly to understanding Wnt signaling in mammals through the generation of knockout mice; however, direct examination of the effects of Wnt signaling in mESCs began in earnest only after the derivation of hESCs. Two groups that generated $\beta$-catenin knockout mESCs used them to generate mouse strains, which convincingly showed the requirement for $\beta$-catenin for gastrulation in mice (Haegel et al. 1995; Huelsken et al. 2000). This early work also 


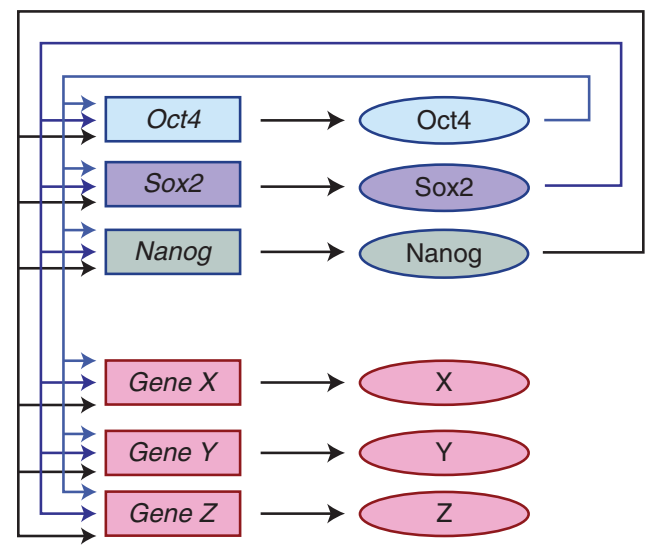

Figure 1. Feed-forward network of stem cell transcription factors. Three transcription factorsOct4, Sox2, and Nanog-bind to one another's gene regulatory regions and control expression of one another's gene products. Downstream targets (genes X, Y, Z) stimulate pluripotent cell self-renewal through the functions of $\mathrm{X}, \mathrm{Y}$, and $\mathrm{Z}$ gene products. (The figure is modeled after those by Cole et al. 2008 and Young 2011.)

directly examined some effects in mESC. Kemler and colleagues used outgrowths from $\beta$-catenin knockout morulae and found that initial formation of ESC-like cells did not require $\beta$ catenin; however, $\beta$-catenin ${ }^{-/-}$cells displayed an adhesion defect causing colonies to appear as loosely associated cells (Haegel et al. 1995). Birchmeier and colleagues generated $\beta$-cate$\operatorname{nin}^{-/-}$mESCs by performing two rounds of homologous recombination and found that the cells self-renewed sufficiently well enough to be used for blastocyst injection experiments (Huelsken et al. 2000). When injected into blastocysts, $\beta$-catenin ${ }^{-1-}$ mESCs could contribute to ectoderm, mesoderm, and endoderm cell types in the embryo (Huelsken et al. 2000). Although they were performed before elucidation of the core pluripotency circuitry, these early observations indicated that $\beta$-catenin was not absolutely necessary for pluripotent cell self-renewal in classical mESC culture conditions ( $\mathrm{LIF}^{+}$, serum, feeders).

A positive effect of Wnt signaling in stimulating self-renewal was shown by a combination of experiments using Wnt-conditioned media, recombinant Wnt, and chemical inhibitors. When cultured without a feeder layer, the withdrawal of recombinant LIF caused mESCs to differentiate (Smith et al. 1988; Williams et al. 1988). This response is measured quite simply by scoring colony morphologies as differentiated (alkaline phosphatase (AP) negative, flattened colony) versus ESC-like ( $\mathrm{AP}^{+}$, rounded birefringent colony) after a period of $4-8 \mathrm{~d}$ of colony growth. Sato et al. (2004) showed that by adding an inhibitor of Gsk3, called BIO, or by adding Wnt3a-conditioned media to cells, exogenous LIF was no longer necessary for the formation of ESC-like colonies or for activity of the Rexl promoter, which is specific for mESC. The conditioned media used in these early experiments probably also contained low levels of LIF or a similar cytokine, because unlike conditioned media, recombinant Wnt3a did not completely replace LIF; instead, recombinant Wnt3a sensitized the cells such that 100fold lower-than-normal levels of exogenous LIF were able to support self-renewal (Ogawa et al. 2006). Similarly, the expression of Wnt6 and Wnt5a supplemented the capability of an ineffective feeder cell layer, called C-STO, into an efficient feeder cell layer that stimulated self-renewal of mESCs (Hao et al. 2006). These effects of Wnts appeared to function through canonical $\beta$-catenin signaling, because forced expression of a stable $\beta$-catenin in MESC was sufficient to allow low levels of exogenous LIF to stimulate self-renewal (Ogawa et al. 2006; Takao et al. 2007), and to allow C-STO feeders cells to function as an effective feeder cell layer (Hao et al. 2006). Each of these findings was important for showing a positive role for Wnt stimulation; however, they also indicated a potentially limited role for Wnts in stimulating self-renewal in the presence of serum-containing media.

Wnt signaling also regulates differentiation of mouse embryonic stem cells. When injected into a permissive site of a host mouse, normal mESCs form teratoma tumors consisting of diverse cell types derived from all three germ layers. Mouse ESCs harboring two mutant alleles of APC either failed to generate teratomas or formed tumors that were particularly deficient for neurectoderm differentiation (Kielman et al. 
2002). The effects of APC mutation were attributed to increased $\beta$-catenin levels because stabilization of $\beta$-catenin through deletion of exon 3 (Harada et al. 1999) resulted in ostensibly the same effects in teratoma and colony-based assays (Kielman et al. 2002). Doble et al. (2007) genetically ablated both alleles of each GSK3 $\alpha$ and GSK3 $\beta$ gene in a single mESC line, named GSK3 DKO for "double knockout." The analysis of GSK3 DKO cells elegantly proved that both GSK $3 \alpha$ and $\beta$ isoforms contributed essentially equally to the regulation of $\beta$-catenin in stem cells (Doble et al. 2007). Tcf- $\beta$-catenin target genes (Axin2, Brachyury, Cdx1) and TOPFlash activity were increased in GSK3 DKO cells without exogenous Wnt, indicating that endogenous GSK3 prevented activation of Wnt/Tcf/ $\beta$-catenin signaling (Doble et al. 2007). Much like APC mutants, GSK3 DKO cells were unable to differentiate normally in either embryoid body (EB) or teratoma differentiation assays; they retained a significant population of cells expressing ESC marker genes, including Nanog, Oct4, and Rex1, whereas wild-type cells generated teratomas expressing diverse lineage markers (Doble et al. 2007; Kelly et al. 2011).

Wnt Signaling Stimulates Long-Term Self-Renewal of Naive mESCs

In addition to the short-term self-renewal and differentiation effects discussed above, several studies examined $\mathrm{Wnt} / \beta$-catenin effects with more stringent tests of self-renewal, such as derivation of ESCs from embryos and long-term self-renewal in vitro. Austin Smith and colleagues noted that signals present in commonly used mESC cultures (serum-containing media) actually included significant differentiation-inducing signals (Ying et al. 2003, 2008; Kunath et al. 2007; Nichols et al. 2009). They posited that mESCs could exist in a ground state of selfrenewal if extracellular signals were blocked. This model was supported by the observations that activation of ERK signaling promoted differentiation of mESCs and that mESC differentiation was constrained by adding an Fgf receptor (Fgfr) inhibitor and an ERK inhibitor (PD0325901) to a chemically defined media
(Ying et al. 2008; Nichols et al. 2009). Using only Fgfr and ERK inhibitors did not sustain mESC cultures, because cells died without undergoing self-renewal divisions. Adding a GSK3 inhibitor alone, such as BIO or CHIR99021, sustained a short burst of self-renewal for only one or two passages (Ying et al. 2008). Remarkably, the combination of the three inhibitors, which was subsequently reduced to only two (PD0325901 + CHIR99021), was quite effective; these so-called two-inhibitor (2i) conditions supported the derivation of new mESC lines from blastocyst outgrowths and expansion into large cultures from a single cell of an already established mESC line (Ying et al. 2008; Nichols et al. 2009). Mouse ESCs grown in $2 \mathrm{i}$ conditions were cultured for several weeks with no apparent defects, and they maintained the ability to contribute to chimeric mice when injected into blastocysts (Ying et al. 2008). Recombinant Wnt3a could essentially replace the CHIR99021 to support self-renewal of mESC colonies + ERK inhibitors (Ying et al. 2008). Other, structurally dissimilar GSK3 inhibitors, RNAi knockdown of GSK3 enzymes, or genetic ablation of GSK3 in DKO cells all could replace CHIR99021, supporting the importance of GSK3 inhibition rather than potential off-target effects of inhibitors (Ying et al. 2008; Wray et al. 2011).

Activation of Wnt signaling or inhibition of GSK3 activity powerfully stimulated self-renewal of mESCs; however, exogenously activating Wnt/ $\beta$-catenin does not appear to be absolutely necessary for pluripotency. The combination of LIF + ERK inhibitor without GSK3 inhibitors was able to support self-renewal of cells, albeit with a significantly lower efficiency than $2 \mathrm{i}$ conditions (Ying et al. 2008; Wray et al. 2011). Similarly, ERK inhibitors could be omitted when LIF was added together with GSK3 inhibition or recombinant Wnt3a (Ying et al. 2008; Berge et al. 2011; Wray et al. 2011). Indeed, some reports show that the positive effect of $\mathrm{Wnt} / \beta$-catenin signaling on self-renewal is substantially greater than that of ERK inhibition (Berge et al. 2011). Consistent with this observation, the combination of exogenous LIF, Wnt3a, or GSK3 inhibitor, and ERK inhibitor 
together stimulated the most robust self-renewal of mESCs (Silva et al. 2008; Ying et al. 2008; Berge et al. 2011; Wray et al. 2011). These findings indicate that pluripotency does not absolutely require any one of the three components, that is, activation of LIF/Jak/Stat3 signaling, inhibition of ERK activity, or exogenous Wntstimulation/GSK3-inhibition.

It is important to note that mESCs secrete active Wnts (Berge et al. 2011). Blocking Wnt secretion from mESCs inhibited mESC selfrenewal in a naive state (Berge et al. 2011). This discovery showed that endogenous Wnt/ $\beta$-catenin contributes an underlying and necessary function for mESC self-renewal. The function is stimulated by exogenously supplied Wnt3a or GSK3 inhibitors to stimulate efficient self-renewal. Although the optimal self-renewal in $2 \mathrm{i}+$ LIF conditions indicates unique effects of each component, the effectiveness of any combination of two components indicates overlapping effects. The identity of the most important downstream effects for self-renewal remains an open topic of research for each component, including Wnt stimulation/GSK3 inhibition.

\section{Effects of Wnt Stimulation and GSK3 Inhibition Depend on the State of Pluripotency}

In contrast to mESCs, long-term self-renewal of hESCs did not benefit significantly from activating the Wnt signaling pathway (Dravid et al. 2005). This difference may be reflective of the differences between a primed versus naive state of pluripotency. Compared with the naive state of mESCs, hESCs more closely resemble the primed state of mEpiSCs (Fig. 1) (Brons et al. 2007; Tesar et al. 2007). Instead of stimulating self-renewal, Wnt signaling effectively stimulated differentiation of mESCs after they have been primed either by growth at a high density (Otero et al. 2004) or by initial commitment in EB assays (Lindsley et al. 2006; ten Berge et al. 2008). Similar to hESCs, EpiSCs responded to inhibiting GSK3 by differentiating (Greber et al. 2010). Interestingly, forced expression of Klf4, c-myc, or Nr5a2 enabled EpiSCs to be convert- ed to a naive state when switched from Fgf2 + Activin A conditions to $2 \mathrm{i}$ conditions (Guo et al. 2009; Hanna et al. 2009; Guo and Smith 2010). This conversion required GSK3 inhibition. It was proposed that Klf4 and Nr5a2 expression effectively reprogrammed cells between metastable states of pluripotency (i.e., from a primed to a naive state), which could then be sustained by $2 \mathrm{i}$ conditions. Together, these observations indicated that GSK3 inhibition stimulated differentiation of the pluripotent cells primed for differentiation, but it stimulated self-renewal of naive pluripotent cells.

The importance of even subtle changes in the cellular state was neatly shown through examination of differences among individual cells in EpiSC cultures. Hans Scholer and colleagues isolated a culture of EpiSCs from an epiblast containing an Oct4-GFP promoter-reporter transgene (Han et al. 2010). Curiously, despite the EpiSC line expressing normal levels of Oct4 mRNA and protein, the Oct4-GFP activity was detectable in only $\sim 0.5 \%$ of the EpiSCs. Although the mechanism underlying the effect on the promoter activity remains unclear, the activation or silencing of Oct4-GFP was dynamic. Sorted GFP-EpiSC cells generated cultures containing $\sim 0.5 \% \mathrm{GFP}^{+}$cells, and $\mathrm{GFP}^{+}$ EpiSC cells generated cultures of predominantly $\mathrm{GFP}^{-}$cells (Han et al. 2010). Thus, EpiSCs moved between the two cellular epigenetic states identified by Oct4-GFP activity. Gene expression signatures and blastocyst injection experiments indicated that $\mathrm{GFP}^{+}$EpiSCs were similar to naive cells from E5.5 embryos, and $\mathrm{GFP}^{-}$ EpiSCs were similar primed cells from E6.5 embryos (Han et al. 2010). When the two populations of cells were subjected to ERK and GSK3 inhibitor conditions, the $\mathrm{GFP}^{-}$cells behaved as described for other EpiSC experiments, and GSK3 inhibition stimulated differentiation. In contrast, GSK3 inhibition plus ERK inhibition caused $\mathrm{GFP}^{+}$cells to revert to an overt ESC-like state. Thus, GSK3 inhibition stimulated self-renewal of cells in the naive state, and it stimulated differentiation of cells in the primed state.

Given the observation that Wnt/ $\beta$-catenin signaling causes different effects on naive cells compared with primed cells, it is interesting to 
note that $\mathrm{Wnt} / \beta$-catenin controls the transition from naive to primed state. Support for this conclusion comes from work by ten Berge, Nusse, and colleagues, who showed that blocking Wnt ligands with Fz8CRD, a soluble Frizzled domain that sequesters Wnt proteins, caused mESCs to adopt EpiSC-like characteristics (ten Berge et al. 2011). Similarly, treating mESCs with IWP2, a porcupine inhibitor that blocks secretion of active Wnt proteins, inhibited $\mathrm{AP}^{+}$colony formation and mESC colony morphology while promoting a switch from naive (Rex1, Pecam1, Stella) to primed (Fgf5, Otx2, Dnmt3b) gene expression. The mechanism of action for IWP2 and Fz8CRD indicated that mESC cells secreted their own Wnt proteins that acted in a paracrine/autocrine manner. The colonies formed in the presence of IWP2 displayed a flattened EpiSC morphology and could be propagated using EpiSC culture conditions (Brons et al. 2007; Tesar et al. 2007; Berge et al. 2011). Together, these observations support a required function for Wnt signaling in preventing the transition from a naive to a primed state of pluripotency.

\section{MECHANISMS OF WNT PATHWAY EFFECTS ON PLURIPOTENT CELLS}

GSK3 Inhibition Functions through $\beta$-Catenin Stability

As is evident from the breadth of areas covered in this collective work, binding of a Wnt ligand to its receptor complex can cause a variety of downstream effects. Although GSK3 activity is necessary for regulating $\beta$-catenin levels, it is also important for cellular effects not normally associated with Wnt signaling, such as glycogen metabolism and translation control (Doble and Woodgett 2003). Moreover, the suggestion that $\beta$-catenin was not genetically necessary for mESCs to proliferate in $\mathrm{LIF}^{+}$serum conditions (Lyashenko et al. 2011; Wray et al. 2011) presented the possibility that $\beta$-catenin-independent effects of GSK3 inhibition and Wnt stimulation may affect pluripotent cell self-renewal. Therefore, it was important to determine if Wnt
stimulation/Gsk3 inhibition affects function through $\beta$-catenin.

Several studies have addressed the role of $\beta$-catenin in mediating GSK3-inhibitor effects by using independent methods of increasing $\beta$-catenin levels in mESCs. When compared side-by-side with either mutating APC (Kielman et al. 2002) or ablating GSK3 in DKO cells (Doble et al. 2007), increasing $\beta$-catenin levels similarly inhibited the appearance of differentiated cell types in teratoma- and EB-based differentiation assays. Overexpression of $\beta$-catenin stimulated LIF-independent self-renewal of mESCs in serum-containing media (Ogawa et al. 2006; Takao et al. 2007). In addition, increasing $\beta$-catenin levels, inhibiting GSK3, or treating cells with Wnt3a all caused similar activation of endogenous target genes (Axin2, Cdx1, Brachyury) and transfected reporter plasmids (TOPFlash, Rex1, Nanog) (Kielman et al. 2002; Sato et al. 2004; Doble et al. 2007; Cole et al. 2008; Yi et al. 2008; Kelly et al. 2011). Thus, increasing $\beta$-catenin levels, inhibiting GSK3 activity, and adding exogenous Wnt3a all were sufficient to cause the similar pro-self-renewal effects on mESCs.

Until recently, surprisingly few studies genetically tested whether $\beta$-catenin was necessary for the effects of Wnts or GSK3 inhibition on pluripotent cells. Bradley Doble and colleagues used RNAi-knockdown techniques to determine whether $\beta$-catenin was necessary for differentiation defects in GSK3 DKO cells (Kelly et al. 2011). Teratomas formed from GSK3 DKO + control shRNA cells, but they failed to generate neurectoderm and retained significant numbers of Nanog-expressing cells. In contrast, GSK3 DKO $+\beta$-catenin-specific shRNA cells generated teratomas containing neurectoderm and lacking Nanog expression, similar to those formed from wild-type mESCs. Thus, $\beta$-catenin was necessary for differentiation defects in GSK3 DKO cells. Another approach independently taken by two groups (Austin Smith's group and Christine Hartmann's group) found that after conditionally ablating $\beta$-catenin from established mESC lines, cells formed abnormally scattered colonies consisting of poorly attached cells (Lyashenko et al. 


\section{B.J. Merrill}

2011; Wray et al. 2011), which was similar to the colony morphology of outgrowths from $\beta$-catenin-null blastocysts (Haegel et al. 1995). Interesting, the abnormal colony morphology returned to normal after several passages despite the continued absence of $\beta$-catenin, most likely because plakoglobin, a homolog of $\beta$-catenin that also binds to E-cadherin, replaced $\beta$-catenin at adherence junctions (Haegel et al. 1995; Huelsken et al. 2000; Lyashenko et al. 2011). Ablating $\beta$-catenin failed to block pluripotent cell proliferation in either $2 \mathrm{i}+$ LIF or LIF + ERK inhibitor conditions (Lyashenko et al. 2011; Wray et al. 2011). $\beta$-Catenin-null cells expressed markers of mESCs, including Oct4, Sox2, Nanog, Rex1, and Pecam1 (Lyashenko et al. 2011; Wray et al. 2011), which was consistent with $\beta$-catenin not being absolutely necessary for pluripotency. In contrast, EpiSC differentiation following IWP2 and Fz8CRD treatments indicated that Wnt signaling was necessary for self-renewal in a naive state (Berge et al. 2011). Thus, either a $\beta$-catenin-independent effect of Wnt proteins contributes to the naive state and/or the $\beta$-catenin-null cells exist in a primed state. Regardless of the state of pluripotency of $\beta$-catenin-deficient cells, it is important to note that the $\beta$-catenin was necessary for self-renewal under either $2 \mathrm{i}$ or LIF + GSK3inhibitor conditions (Lyashenko et al. 2011; Wray et al. 2011), showing that $\beta$-catenin is the necessary downstream effector of GSK3 inhibition. Thus, the ability of GSK3 inhibition to support long-term self-renewal functions through $\beta$-catenin.

Exactly how $\beta$-catenin exerts pro-self-renewal effects in ESCs has been a somewhat controversial question, and it remains an emerging topic of research at the time of this article's preparation. All four Tcf/Lef proteins are expressed in mESCs (Pereira et al. 2006; Kelly et al. 2011); comparing Tcf/Lef mRNA levels with quantitative RT-PCR assays revealed that Tcf3 was by far the most abundant (Pereira et al. 2006). A wealth of data shows that Tcf3 plays an important role in regulating the self-renewal and differentiation of mESCs; however, some data reveal $\beta$-catenin activities that are independent of a Tcf3- $\beta$-catenin transactivator com- plex. Interestingly, research from other systems indicated that $\mathrm{Tcf} 3$ appears to be unique among $\mathrm{Tcf} /$ Lef proteins in terms of effects on target genes and the biochemical interactions that affect activities (Hikasa et al. 2010; Hikasa and Sokol 2011), supporting the potential for an unconventional effect of mammalian Tcf3 proteins in response to $\mathrm{Wnt} / \beta$-catenin signaling. Below, a current view is presented regarding the underlying molecular mechanisms by which $\beta$ catenin stimulates self-renewal in pluripotent cells.

\section{Potential Tcf-Independent Mechanisms:} The $\beta$-Catenin-Oct4 Interaction

A physical interaction between $\beta$-catenin and Oct 4 was first suggested by Takao et al. (2007) to be important for mESC self-renewal, and it was mechanistically expanded in subsequent work by several groups. Yehudit Bergman and colleagues found that Oct 4 inhibited Tcf- $\beta$ catenin transcriptional activity in mESCs (Abu-Remaileh et al. 2010). The $\beta$-cateninOct4 interaction appears to be evolutionarily conserved, and Xenopus Oct4 homologs (Oct60 and Oct-25) inhibited transcription of $\beta$ catenin-regulated genes during germ layer specification (Cao et al. 2007; Abu-Remaileh et al. 2010). An essentially identical effect of Oct4 inhibiting $\beta$-catenin stimulation of TOPFlash activity also occurred in the P19 embryoid carcinoma cell line (Marikawa et al. 2011). This Oct4 effect in P19 cells was shown to be cellautonomous; however, overexpression of an Oct4-engrailed repressor fusion protein stimulated TOPFlash, whereas an Oct4-VP16 transactivator fusion protein inhibited TOPFlash activity. Although the heterologous nature of the Oct4-fusion proteins makes this experiment somewhat difficult to interpret, it indicates that the Oct4 regulation of $\mathrm{Tcf}-\beta$-catenin transcriptional activity works through some mechanism other than Oct4 directly recruiting corepressors or coactivators to $\mathrm{Tcf}-\beta$-catenin complexes.

The Oct $4-\beta$-catenin interaction was suggested to regulate $\beta$-catenin degradation. When Oct4 levels were genetically reduced in mESCs, 
total cellular levels of $\beta$-catenin increased; when Oct4 was increased, $\beta$-catenin levels decreased (Abu-Remaileh et al. 2010). The Oct4-mediated decrease in $\beta$-catenin was blocked by mutating GSK3-phosphorylation sites in $\beta$-catenin, by inhibiting the proteasome with MG132, or by mutating APC (Abu-Remaileh et al. 2010). In P19 cells, knocking down Oct4 stimulated several genes (Sp5, Wnt3, and Eomes), and this effect was significantly reduced by $\beta$-catenin shRNA (Marikawa et al. 2011). Taken together, these results were interpreted to suggest that $\beta$-catenin stimulates differentiation of mESC, and Oct4 promotes self-renewal by inhibiting $\beta$-catenin's pro-differentiation effect. Although this model draws appeal from consistency with some embryonic data showing that $\mathrm{Wnt} / \beta$-catenin stimulates differentiation of primed cells toward mesoderm and endoderm lineages, it conflicts with observations that increasing $\beta$ catenin levels stimulated self-renewal and inhibited differentiation of naive mESCs. As such, it appears to be most relevant when considering the pro-differentiation effect of $\beta$-catenin specifically for cells in the primed state of pluripotency.

Tcf-independent mechanisms for $\beta$-catenin were also examined in GSK3 DKO cells. Stable expression of $\Delta$ NTcf4 in GSK3 DKO cells strikingly reduced the activation of well-characterized Tcf- $\beta$-catenin targets (TOPFlash, Axin2, $\mathrm{Cdx} 1$, Brachyury), indicating that $\Delta \mathrm{NTcf} 4$ expression effectively blocked transactivation by Tcf- $\beta$-catenin complexes (Kelly et al. 2011). Importantly, the expression of $\Delta$ NTcf 4 did not restore differentiation competence to GSK3 DKO cells, because teratomas and EBs made from GSK3 DKO $+\Delta \mathrm{NTcf} 4 \mathrm{mESC}$ lacked neurectoderm and maintained Oct4 and Nanog expression. In contrast, $\beta$-catenin shRNA restored differentiation competence to DKO + Tcf4DN cells. In addition, forced expression of a $\beta$-catenin mutant ( $\beta$ cat33A $\Delta \mathrm{C}$ ) failed to substantially activate Tcf- $\beta$-catenin targets (TOPFlash, Axin2, Cdx1, Brachyury), but it inhibited neurectoderm differentiation similar to forced expression of a fully functional, stable $\beta$-catenin (Kelly et al. 2011). Thus, there was a clear genetic separation of function between the activation of classical Tcf- $\beta$-catenin targets and the inhibition of differentiation. These observations strongly indicate an unconventional mechanism whereby $\beta$-catenin stimulates self-renew$\mathrm{al}$, that is, one that does not require Tcf- $\beta$-catenin activator complexes. Doble and colleagues suggested that Oct4 may recruit $\beta$-catenin to promoters and Oct $4-\beta$-catenin complexes transcriptionally activate Oct4-bound self-renewal genes (Kelly et al. 2011). Although this model provides a possible explanation for prodifferentiation and pro-self-renewal effects of Wnt-stabilized $\beta$-catenin, it does not account for the role and activity of endogenously expressed Tcf/Lefs, including Tcf3.

Tcf Regulation of Wnt/ $\beta$-Catenin Stimulation of Self-Renewal: Integral Role of Tcf3 in the Core Stem Cell Self-Renewal Network

Loss-of-function experiments showed that Tcf3 mediates important effects on the self-renewal of mESCs. Initial experiments showed that genetic ablation of Tcf3 allowed Tcf $3^{-/}$mESCs to self-renew in serum-containing media without LIF/Jak/Stat3 signaling (Pereira et al. 2006; Yi et al. 2008; Yi and Merrill 2010; Wray et al. 2011). Tcf3 $^{-/-}$mESCs also displayed delayed differentiation in EB assays and colony-based differentiation assays (Pereira et al. 2006; Yi et al. 2008; Wray et al. 2011). Thus, genetic ablation of endogenous Tcf3 caused effects that were similar to ectopic activation of $\mathrm{Wnt}-\beta$-catenin signaling. Similarly, RNAi knockdown of total Tcf3 in mESCs stimulated the formation of ESC-like colonies in the absence of exogenous LIF (Cole et al. 2008), inhibited differentiation in monolayers treated with retinoic acid (Tam et al. 2008), and prevented EBs from developing a differentiated morphology (Tam et al. 2008). Conklin and colleagues found that mESCs express two Tcf3 isoforms at essentially equal levels (Salomonis et al. 2010); knockdown of either Tcf3 isoform was sufficient to inhibit differentiation in colony-based and EB-based differentiation assays, indicating that halving Tcf3 levels was sufficient to stimulate self-renewal (Salomonis et al. 2010). 


\section{B.J. Merrill}

An important role for Tcf3 was confirmed with unbiased forward genetic screens performed using mESCs. Patrick Paddison and colleagues used a library of shRNAs enriched for gene targets involved in chromatin regulation, signal transduction, and transcription (Schaniel et al. 2009). They transfected shRNAs into mESCs harboring a Nanog-GFP reporter, and cells were treated with retinoic acid, which induces differentiation and reduces NanogGFP activity. Tcf3 was one of the 12 targets whose knockdown allowed the maintenance of Nanog-GFP levels after retinoic acid. In a separate phenotype-driven genetic screen, the $\mathrm{Blm}^{-}$ mutator mESC system (Guo et al. 2004) was combined with PiggyBAC mutagenesis (Ding et al. 2005; Wang et al. 2008) to identify recessive mutations that inhibited neural differentiation in a colony-based assay (Guo et al. 2011). This pilot screen of 2000 random mutant mESC lines recovered five lines that failed to differentiate when stimulated; all five harbored a mutation in the Tcf3 gene and were likely identical by descent (Guo et al. 2011). The Tcf3 mutations were proven to be the cause of neurectoderm differentiation defects, because the defect was complemented with expression of wildtype Tcf3 protein. Interestingly, this same study reported that $\mathrm{Tcf}^{+/-}$heterozygotes also displayed differentiation defects, consistent with the importance of the amount of Tcf3 in ESCs. Combined with results from the approaches that specifically targeted Tcf3, these unbiased screens show a central role for Tcf3 in mESC self-renewal and differentiation.

A breakthrough in understanding the mechanism of Wnt/ $\beta$-catenin regulation of selfrenewal came when Richard Young and colleagues examined the chromatin occupancy of Tcf3 in mESCs (Cole et al. 2008). They performed ChIP-on-chip and ChIP-seq experiments using an anti-Tcf3 antibody side-byside with antibodies directed against Oct4, Sox2, and Nanog. Their results confirmed the co-occupancy of Oct4/Sox2/Nanog at common genes (Boyer et al. 2005; Loh et al. 2006), and they also observed an impressive amount of overlap with the occupancy of Tcf3 at the same genes (Cole et al. 2008; Marson et al. 2008).
Independently performed ChIP-on-chip experiments by Bing Lim and colleagues also reported overlap in the genes bound by Tcf3 and those bound by Oct 4 and Nanog (Tam et al. 2008). Perhaps the best illustration of co-occupancy came from ChIP-seq experiments, which showed that of the 1369 known genes identified as Tcf3-bound, 1173 were also bound by Oct4, and 942 were bound by each, Tcf3, Oct4, Sox2, and Nanog (Marson et al. 2008). Other studies showed Oct4 and Nanog mRNA and protein levels were increased when Tcf3 was knocked down or ablated (Pereira et al. 2006; Cole et al. 2008; Tam et al. 2008; Salomonis et al. 2010; Wagner et al. 2010). Transcriptional profiling of $\mathrm{Tcf} 3^{-/-}$ESCs showed that Tcf3 ablation caused strongly opposite effects on gene expression compared with Oct4 knockdown and Nanog knockdown (Loh et al. 2006; Yi et al. 2008). It is notable that the effect on Oct4-regulated genes was measured in $\mathrm{Tcf} 3^{-/}$cells, which did not display elevated Oct4 protein levels (Pereira et al. 2006; Yi et al. 2008), and that knockdown of Nanog in Tcf3 ${ }^{-/-}$cells did not reduce the levels of stem cell genes examined ( $\mathrm{Yi}$ et al. 2011). Thus, the effects of Tcf3 ablation went beyond just Nanog and Oct4 stimulation and appeared to directly affect the genes co-occupied by Tcf3/Oct4/Sox $2 /$ Nanog. These results effectively integrated Tcf3 within the core self-renewal network and suggested that Tcf3 functioned as a limiter that restrains activity of the Oct4/Sox2/Nanog network (Yi et al. 2008).

\section{Wnt-Stabilized $\beta$-Catenin Functions through} Tcf-Dependent Mechanisms in mESCs

An early model suggested that Tcf3- $\beta$-catenin transactivator complexes directly stimulate expression of Tcf3/Oct4/Sox $2 /$ Nanog-bound stem cell genes in response to Wnt signaling (Cole et al. 2008). Although this model was consistent with the observation that Wnt3a stimulated genes that were bound by $\mathrm{Tcf} 3$ more frequently than those not bound by Tcf3 in mESCs (Cole et al. 2008), it was not consistent with molecular activities reported for Tcf3 in mESCs. For example, ChIP experiments showed that Tcf3 bound directly to enhancer 
regions of Nanog and Oct4 genes, which were increased by Tcf3 ablation (Pereira et al. 2006; Cole et al. 2008; Marson et al. 2008; Tam et al. 2008). Luciferase reporter experiments showed that Tcf3 directly repressed Nanog and Oct4 promoter activity (Pereira et al. 2006; Tam et al. 2008). Repression of Oct4 and Nanog promoters required DNA binding and the context regulator domain of Tcf3 but did not require $\beta$ catenin interaction (Roose et al. 1998; Arce et al. 2006; Pereira et al. 2006; Tam et al. 2008). Tam et al. (2008) reported that a protein recognized by a Tle2 antibody co-occupied Tcf3 sites by ChIP analysis and suggested that $\mathrm{Tcf} 3-\mathrm{Grg}$ complexes repress target genes in mESCs. Thus, there is strong evidence supporting Tcf3-repressor activity in mESCs and very little support for a Tcf3-activator activity in mESCs. Moreover, the separation of function observed between activation of Tcf- $\beta$-catenin targets and differentiation defects (Kelly et al. 2011) indicated that even if Tcf3- $\beta$-catenin complexes activated target genes, this was unlikely to be important for stimulating self-renewal.

An updated model explaining Tcf3's role in mESCs suggests that endogenous Tcf3 actually inhibits the self-renewal network via its repressor activity, and Wnt-stabilized $\beta$-catenin suppresses Tcf3-mediated repression. This model is directly supported by several recent observations: Overexpression of Tcf3 inhibited stem cell gene expression (Nishiyama et al. 2009) and stimulated rapid differentiation of mESCs (Yi et al. 2011). Treating Tcf3-overexpressing mESCs with Wnt3a effectively blocked differentiation and restored self-renewal (Yi et al. 2011). $\mathrm{Tcf3}^{-/-}$mESCs self-renewed in serum-free conditions without the addition of LIF or a GSK3 inhibitor, that is, in the presence of ERK inhibitor alone (Wray et al. 2011; Yi et al. 2011), indicating that ablation of Tcf3 effectively replaced the GSK3 inhibitor. Thus, the pro-selfrenewal effects of $\mathrm{Wnt} / \beta$-catenin signaling in mESCs appear to function by inhibiting Tcf3repressor activity.

Austin Smith and colleagues suggested overexpressed $\beta$-catenin $\Delta C$ proteins, such as those used in several studies (Kelly et al. 2011; Lyashenko et al. 2011; Wray et al. 2011), compete with Grg corepressor proteins for binding to Tcf3 (Daniels and Weis 2005). This causes $\beta$ catenin $\Delta \mathrm{C}$ to inhibit $\mathrm{Tcf} 3$ repressor activity, and the self-renewal stimulating ability of $\beta$-cate$\operatorname{nin} \Delta \mathrm{C}$ proteins supports a model wherein the inhibition of Tcf3 repression is the important activity necessary for self-renewal (Wray et al. 2011). However, Wnt $/ \beta$-catenin clearly has additional activities in mESCs, as shown by stimulation of TOPFlash, Axin2, Cdx1, and Brachyury expression (Kielman et al. 2002; Doble and Woodgett 2003; Kelly et al. 2011; Yi et al. 2011). These observations bring forward a question of what is the role for $\beta$-catenin-mediated transactivation of those target genes not repressed by Tcf3 in mESCs. Transcriptional profiling of $\mathrm{Tcf3}^{+/+}$and $\mathrm{Tcf3}^{-1-}$ mESC treated with Wnt3a addressed this possibility by revealing two distinct groups of Wnt3a-regulated genes: (1) those that were similarly increased by Tcf3 ablation and Wnt3a treatment and (2) those that were similarly increased by Wnt $3 \mathrm{a}$ in $\mathrm{Tcf}^{-/-}$and $\mathrm{Tcf3}^{+/+}$cells (Fig. 2) (Yi et al. 2011). Wnt3a effects on Group 1 genes correlated strongly with effects caused by Oct4, indicating that the Wnt3a suppression of Tcf3-repressed genes was important for self-renewal. Wnt3a effects on Group 2 genes did not correlate with effects caused by Oct4, indicating that activation by Wnt3a was unlikely to stimulate self-renewal. Moreover, the Group 2 genes were expressed at much lower levels in mESCs compared with Group 1 genes (Yi et al. 2011). Given the role of Wnt/ $\beta$-catenin signaling in stimulating mesoderm formation in embryos and embryoid bodies, it is tempting to speculate that genes following Group 2-like responses would be important for the differentiation effects of Wnt signaling (see Fig. 3).

Precisely how Wnt 3 a derepresses Tcf 3 targets in mESCs involves multiple molecular mechanisms and is not yet fully elucidated. Several experiments showed that the Tcf3- $\beta$-catenin interaction was important (Wray et al. 2011; Yi et al. 2011); however, the ability of Wnt3a to elevate the already high levels of stem cell gene expression in $\mathrm{Tcf} 3^{-/-}$mESCs revealed an additional effect that did not require Tcf3 (Yi et al. 2011). Tcf1 protein is expressed in 
B.J. Merrill
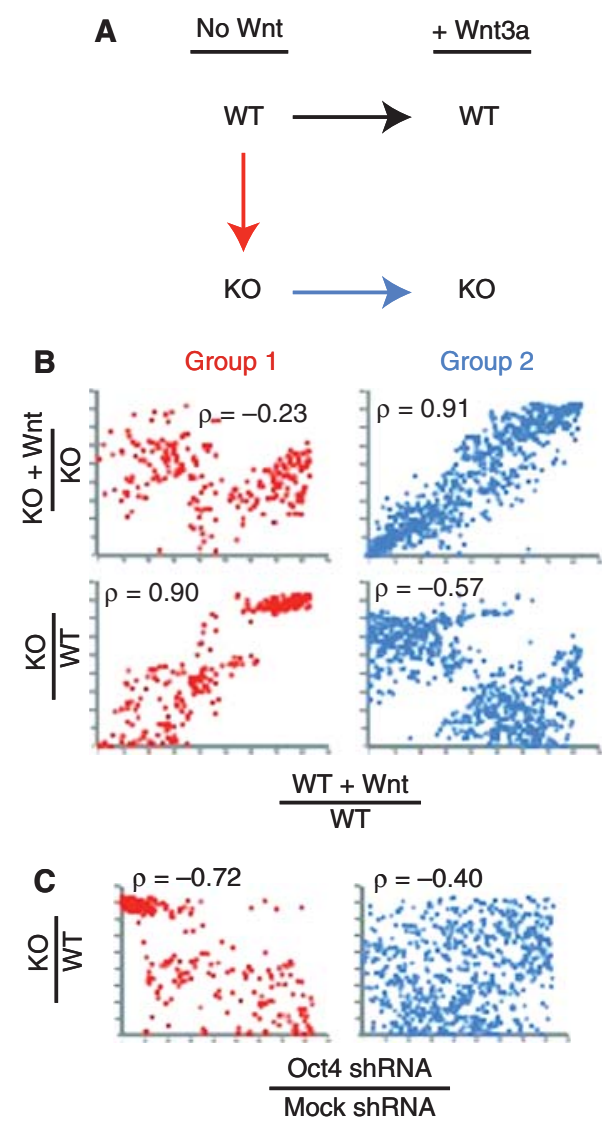

Figure 2. Relationship between Tcf3 and Wnt3a stimulation of gene expression. (A) Design of analysis shown in $B$. Genechip microarray data were acquired for $\mathrm{Tcf}^{+/+}$mESCs (WT, wild type) and Tcf3 $3^{-/-}$ mESCs (KO, knockout) both without Wnt treatment or $24 \mathrm{~h}$ after Wnt3a treatment. Genes stimulated by Wnt3a or ablation of Tcf3 were categorized into two groups by comparing the effect of Wnt3a on WT (black arrow) with the effect of ablating Tcf3 (red arrow) and the effect of Wnt3a on KO (blue arrow). When the magnitude of the effect of Wnt3a (black arrow) was more similar to ablating Tcf3 (red arrow) than to Wnt3a on KO (blue arrow), the gene was assigned to Group 1 (red dot). When the magnitude of the effect of Wnt3a (black arrow) was more similar to Wnt3a on KO (blue arrow) than to ablating Tcf3 (red arrow), the gene was assigned to Group 2 (blue dot). (B) Each point represents a single gene and is plotted according to its rank-fold-effect for the comparisons shown on each axis. Pearson correlation coefficients indicate the relative strength of each relationship. Wnt3a stimulation of Group 1 genes in WT correlated well $(\rho=0.90)$ with ablation of Tcf3 but correlated poorly $(\rho=-0.23)$ with Wnt3a stimulation in KO. Thus, Wnt3a effects on Group 1 genes were most similar to suppression of Tcf3-mediated repression. Conversely, Wnt3a stimulation of Group 2 genes in WT correlated well $(\rho=0.91)$ with Wnt3a stimulation in $\mathrm{KO}$, indicating that Group 2 genes were activated by Wnt3a in a Tcf3-indpendent manner. $(C)$ The effect of Oct4 shRNA ( $x$-axis) on Group 1 (red dot) and Group 2 (blue dot) genes is compared with the effect of Tcf3 ablation ( $y$-axis). Oct 4 shRNA and Tcf3 ablation displayed a strong anti-correlation $(\rho=$ -0.72 ) for Group 1 genes. A similar relationship was reported for Wnt3a on WT compared with Oct4 shRNA (data not shown). The relationships are consistent with Wnt3a suppression of Tcf3 repression being important for expression of Oct4-regulated, stem-cell genes. (Analyses and data are from Yi et al. 2011.)

mESCs (Kelly et al. 2011; Yi et al. 2011); unlike Tcf3, Tcf1 functioned as a transcriptional activator (Yi et al. 2011). The highly conserved HMG domain shared by Tcf1 and Tcf3 enables direct competition for regulation of target genes. Indeed, Wnt3a stimulated $\beta$-catenin recruitment to sites of Tcf3/Oct $4 /$ Sox $2 / \mathrm{Nanog}$ DNA occupancy, and significant $\beta$-catenin recruitment was partially dependent on each Tcf3 and Tcf1 (Yi et al. 2011). In contrast, Oct4 was not able to recruit $\beta$-catenin to $\mathrm{mESC}$ chromatin without Tcf3/Tcfl; notably, this finding is inconsistent with the hypothesis that $\beta$-catenin stimulates the pluripotency network through Oct $4-\beta$-catenin coactivator complexes (Kelly et al. 2011). Combined with gene expression experiments, the $\beta$-catenin ChIP experiments showed that Tcf3 recruited $\beta$-catenin to target genes, yet Tcf3- $\beta$-catenin complexes were apparently ineffective at activating target genes in mESCs, whereas Tcfl- $\beta$-catenin complexes were sufficient to activate genes.

When considering the relative contribution of Tcf3- $\beta$-catenin and Tcf1- $\beta$-catenin interactions for maintenance of naive cell self-renewal, the effects of Tcf3 are more substantial. For example, Tcf1 shRNA reduced Wnt3a's stimulation of $\mathrm{AP}^{+}$colonies in $\mathrm{Tcf3}^{+/+}$mESCs, but that effect was significantly smaller than the stimulation of $\mathrm{AP}^{+}$colony formation caused by 
A Normal ESC self-renewal
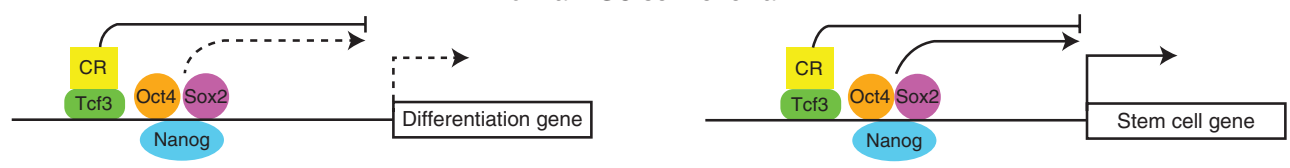

B Tcf3 overexpression $\rightarrow \downarrow$ self-renewal
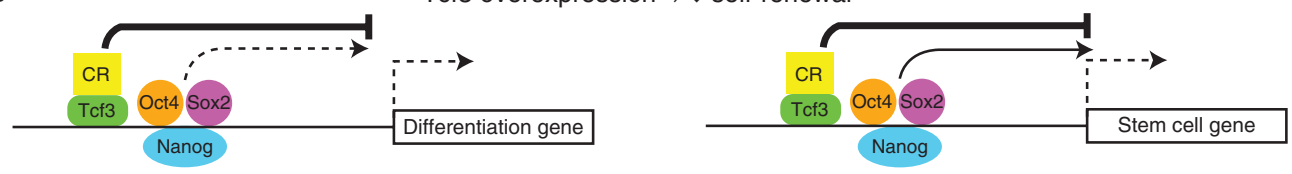

C

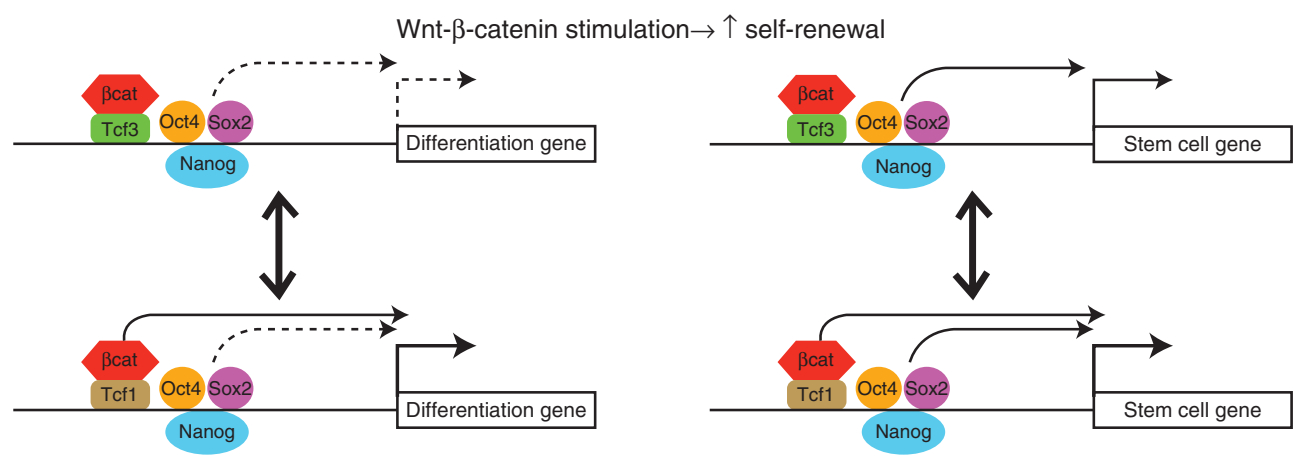

Figure 3. Model depicting effects of Wnt-stabilized $\beta$-catenin through Tcf proteins in mESCs. The two types of Wnt-regulated genes model the regulatory effects of Wnt3a and Tcf3 shown in Figure 2. Group 1 genes are modeled as "Stem cell gene," and Group 2 genes are modeled as "Differentiation gene." $(A)$ The stem cell gene is expressed in self-renewing mESCs as a consequence of Oct4/Sox2/Nanog binding. Tcf3-corepressor (CR) interactions limit stem cell gene expression, but the effects of Tcf3-CR are counteracted by Oct4/Sox $2 /$ Nanog. For simplicity, the Tcf complexes and Oct4/Sox2/Nanog complexes occupy the same DNA strand; however, mutual exclusive and competitive binding of factors is also possible. The differentiation gene is unaffected by Tcf3-corepresor effects because it is not transcriptionally activated by other factors. Note that the differential effect of Oct $4 /$ Sox $2 / N a n o g$ on stem cell versus differentiation genes has been observed; however, the mechanism underlying the different effects remains unclear. $(B)$ Overexpression of Tcf3 reduces expression of stem cell genes by recruiting corepressor activity. The repression of essential stem cell genes is sufficient to promote differentiation, because other differentiation-inducing genes (i.e., those not regulated by Tcf) direct cell fate. (C) Wnt3a stimulates $\beta$-catenin stability, which binds to endogenous Tcf1 and Tcf3 proteins. Tcf3- $\beta$-catenin complexes bind to DNA and block the effects of Tcf3-CR complexes. Note that the same downstream effect could also be caused by Wnt-mediated reduction of Tcf3-DNA occupancy via posttranslational modification, such as phosphorylation by HIPK kinases described for XTCF-3 (Hikasa et al. 2010; Hikasa and Sokol 2011). Tcf1 - $\beta$-catenin stimulates expression of both stem cell genes and differentiation genes; however, the high level of stem cell gene expression is sufficient to stimulate self-renewal.

Tcf3 ablation (Yi et al. 2008, 2011; Wray et al. 2011). It may be helpful to consider that Tcf3 binding to an already silent gene is relatively inconsequential, whereas the greatest effect of Tcf3 binding occurs on those target genes that are being activated through another transcriptional mechanism (for simplicity, Oct4/Sox2/ Nanog complexes are shown as putative activa- tors in Fig. 3). Therefore, Wnt $/ \beta$-catenin inhibition of Tcf3 can be thought of as a stabilizer of the pluripotent state. In contrast, $\mathrm{Wnt} / \beta$-catenin activation of silent genes in mESCs occurs through Tcf1 and can be thought of as a destabilizer of the pluripotent state or driver to a new cellular state. This model predicts that in naive cells, the effects of inhibiting Tcf3 dominate 
B.J. Merrill

over the activating Tcf1. In primed cells, the effects of activating Tcfl dominate over inhibiting Tcf3. A barrier to testing this model comes from the poor understanding of the biochemical mechanisms underlying the opposite activities of Tcf1 and Tcf3. Determining what makes Tcf3 different from the other Tcf/Lef proteins in mESCs should provide important insights into the self-renewal and differentiation of pluripotent cells.

\section{CONCLUDING REMARKS}

Recently, it has become clear that the so-called pluripotent cellular state described for early embryonic cells exists in several different variations. In the naive state of mESCs, Wnt $/ \beta$-catenin signaling stimulates self-renewal by inhibiting the repressor activity of endogenously expressed Tcf3. The effect of Wnt $/ \beta$-catenin signaling on naive cells effectively prevents them from transitioning into a primed state (Berge et al. 2011). Interestingly, once a cell has overcome $W n t / \beta$-catenin effects and entered a primed state of pluripotency, $\mathrm{Wnt} / \beta$-catenin stimulates differentiation through activation of classical Tcf- $\beta$-catenin target genes, such as Brachyury (Arnold et al. 2000; Lickert et al. 2005). Future research must elucidate more incisive differences between naive and primed pluripotent cells and how those differences cause Wnt $/ \beta$ catenin signaling to stimulate remarkably opposite effects on the two cellular states.

\section{ACKNOWLEDGMENTS}

I apologize to the investigators whose contributions were not covered in this work because of space constraints. The author's research is supported by grants from the NIH (CA128571) and ACS (RSG GGC 112994).

\section{REFERENCES}

Abu-Remaileh M, Gerson A, Farago M, Nathan G, Alkalay I, Zins Rousso S, Gur M, Fainsod A, Bergman Y. 2010. Oct$3 / 4$ regulates stem cell identity and cell fate decisions by modulating $\mathrm{Wnt} / \beta$-catenin signalling. EMBO J 29: 3236-3248.

Arce L, Yokoyama NN, Waterman ML. 2006. Diversity of LEF/TCF action in development and disease. Oncogene 25: $7492-7504$.
Arnold SJ, Stappert J, Bauer A, Kispert A, Herrmann BG, Kemler R. 2000. Brachyury is a target gene of the Wnt/ $\beta$-catenin signaling pathway. Mech Dev 91: 249-258.

Avilion AA, Nicolis SK, Pevny LH, Perez L, Vivian N, LovellBadge R. 2003. Multipotent cell lineages in early mouse development depend on SOX2 function. Genes Dev 17: $126-140$.

Beddington RS. 1982. An autoradiographic analysis of tissue potency in different regions of the embryonic ectoderm during gastrulation in the mouse. J Embryol Exp Morphol 69: $265-285$.

Beddington RS. 1983. Histogenetic and neoplastic potential of different regions of the mouse embryonic egg cylinder. J Embryol Exp Morphol 75: 189-204.

Berge DT, Kurek D, Blauwkamp T, Koole W, Maas A, Eroglu E, Siu RK, Nusse R. 2011. Embryonic stem cells require Wnt proteins to prevent differentiation to epiblast stem cells. Nat Cell Biol 13: 1070-1075.

Boyer LA, Lee TI, Cole MF, Johnstone SE, Levine SS, Zucker JP, Guenther MG, Kumar RM, Murray HL, Jenner RG, et al. 2005. Core transcriptional regulatory circuitry in human embryonic stem cells. Cell 122: 947-956.

Brons IG, Smithers LE, Trotter MW, Rugg-Gunn P, Sun B, Chuva de Sousa Lopes SM, Howlett SK, Clarkson A, Ahrlund-Richter L, Pedersen RA, et al. 2007. Derivation of pluripotent epiblast stem cells from mammalian embryos. Nature 448: 191-195.

Cao Y, Siegel D, Donow C, Knochel S, Yuan L, Knochel W. 2007. POU-V factors antagonize maternal VegT activity and $\beta$-catenin signaling in Xenopus embryos. EMBO J 26: 2942-2954.

Chambers I, Colby D, Robertson M, Nichols J, Lee S, Tweedie S, Smith A. 2003. Functional expression cloning of Nanog, a pluripotency sustaining factor in embryonic stem cells. Cell 113: 643-655.

Chambers I, Silva J, Colby D, Nichols J, Nijmeijer B, Robertson M, Vrana J, Jones K, Grotewold L, Smith A. 2007. Nanog safeguards pluripotency and mediates germline development. Nature 450: 1230-1234.

Chen X, Xu H, Yuan P, Fang F, Huss M, Vega VB, Wong E, Orlov YL, Zhang W, Jiang J, et al. 2008. Integration of external signaling pathways with the core transcriptional network in embryonic stem cells. Cell 133: 1106-1117.

Cole MF, Johnstone SE, Newman JJ, Kagey MH, Young RA. 2008. Tcf3 is an integral component of the core regulatory circuitry of embryonic stem cells. Genes Dev 22: $746-755$.

Daniels DL, Weis WI. 2005. $\beta$-Catenin directly displaces Groucho/TLE repressors from Tcf/Lef in Wnt-mediated transcription activation. Nat Struct Mol Biol 12: 364371.

Davis S, Aldrich TH, Stahl N, Pan L, Taga T, Kishimoto T, Ip NY, Yancopoulos GD. 1993. LIFR $\beta$ and gp130 as heterodimerizing signal transducers of the tripartite CNTF receptor. Science 260: 1805-1808.

Ding S, Wu X, Li G, Han M, Zhuang Y, Xu T. 2005. Efficient transposition of the piggyBac (PB) transposon in mammalian cells and mice. Cell 122: 473-483.

Doble BW, Woodgett JR. 2003. GSK-3: Tricks of the trade for a multi-tasking kinase. J Cell Sci 116: 1175-1186. 
Doble BW, Patel S, Wood GA, Kockeritz LK, Woodgett JR. 2007. Functional redundancy of GSK-3 $\alpha$ and GSK-3 $\beta$ in Wnt/ $\beta$-catenin signaling shown by using an allelic series of embryonic stem cell lines. Dev Cell 12: 957-971.

Dravid G, Ye Z, Hammond H, Chen G, Pyle A, Donovan P, Yu X, Cheng L. 2005. Defining the role of Wnt/beta-catenin signaling in the survival, proliferation, and self-renewal of human embryonic stem cells. Stem Cells 23: 1489-1501.

Evans MJ, Kaufman MH. 1981. Establishment in culture of pluripotential cells from mouse embryos. Nature 292: $154-156$.

Gearing DP, Bruce AG. 1992. Oncostatin M binds the highaffinity leukemia inhibitory factor receptor. New Biol 4: $61-65$.

Gearing DP, Thut CJ, VandeBos T, Gimpel SD, Delaney PB, King J, Price V, Cosman D, Beckmann MP. 1991. Leukemia inhibitory factor receptor is structurally related to the IL-6 signal transducer, gp130. EMBO J 10: 28392848.

Greber B, Wu G, Bernemann C, Joo JY, Han DW, Ko K, Tapia N, Sabour D, Sterneckert J, Tesar P, et al. 2010. Conserved and divergent roles of FGF signaling in mouse epiblast stem cells and human embryonic stem cells. Cell Stem Cell 6: $215-226$.

Gu P, Goodwin B, Chung AC, Xu X, Wheeler DA, Price RR, Galardi C, Peng L, Latour AM, Koller BH, et al. 2005. Orphan nuclear receptor LRH-1 is required to maintain Oct4 expression at the epiblast stage of embryonic development. Mol Cell Biol 25: 3492-3505.

Guo G, Smith A. 2010. A genome-wide screen in EpiSCs identifies Nr5a nuclear receptors as potent inducers of ground state pluripotency. Development 137: 3185-3192.

Guo G, Wang W, Bradley A. 2004. Mismatch repair genes identified using genetic screens in Blm-deficient embryonic stem cells. Nature 429: 891-895.

Guo G, Yang J, Nichols J, Hall JS, Eyres I, Mansfield W, Smith A. 2009. Klf4 reverts developmentally programmed restriction of ground state pluripotency. Development 136: $1063-1069$.

Guo G, Huang Y, Humphreys P, Wang X, Smith A. 2011. A PiggyBac-based recessive screening method to identify pluripotency regulators. PLOS ONE 6: e18189. doi: 10.1371/journal.pone.0018189.

Haegel H, Larue L, Ohsugi M, Fedorov L, Herrenknecht K, Kemler R. 1995. Lack of $\beta$-catenin affects mouse development at gastrulation. Development 121: 3529-3537.

Hall J, Guo G, Wray J, Eyres I, Nichols J, Grotewold L, Morfopoulou S, Humphreys P, Mansfield W, Walker R, et al. 2009. Oct4 and LIF/Stat3 additively induce Kruppel factors to sustain embryonic stem cell self-renewal. Cell Stem Cell 5: 597-609.

Han DW, Tapia N, Joo JY, Greber B, Arauzo-Bravo MJ, Bernemann C, Ko K, Wu G, Stehling M, Do JT, et al. 2010. Epiblast stem cell subpopulations represent mouse embryos of distinct pregastrulation stages. Cell 143: 617627.

Hanna J, Markoulaki S, Mitalipova M, Cheng AW, Cassady JP, Staerk J, Carey BW, Lengner CJ, Foreman R, Love J, et al. 2009. Metastable pluripotent states in NOD-mousederived ESCs. Cell Stem Cell 4: 513-524.
Hao J, Li TG, Qi X, Zhao DF, Zhao GQ. 2006. WNT/ $\beta$ catenin pathway up-regulates Stat 3 and converges on LIF to prevent differentiation of mouse embryonic stem cells. Dev Biol 290: 81-91.

Harada N, Tamai Y, Ishikawa T, Sauer B, Takaku K, Oshima M, Taketo MM. 1999. Intestinal polyposis in mice with a dominant stable mutation of the $\beta$-catenin gene. $E M B O J$ 18: 5931-5942.

Heisenberg CP, Solnica-Krezel L. 2008. Back and forth between cell fate specification and movement during vertebrate gastrulation. Curr Opin Genet Dev 18: 311-316.

Hikasa H, Sokol SY. 2011. Phosphorylation of TCF proteins by homeodomain-interacting protein kinase 2 . J Biol Chem 286: 12093-12100.

Hikasa H, Ezan J, Itoh K, Li X, Klymkowsky MW, Sokol SY. 2010. Regulation of TCF3 by Wnt-dependent phosphorylation during vertebrate axis specification. Dev Cell 19: $521-532$.

Hochedlinger K, Plath K. 2009. Epigenetic reprogramming and induced pluripotency. Development 136: 509-523.

Huelsken J, Vogel R, Brinkmann V, Erdmann B, Birchmeier C, Birchmeier W. 2000. Requirement for $\beta$-catenin in anterior-posterior axis formation in mice. $J$ Cell Biol 148: $567-578$.

Ivanova N, Dobrin R, Lu R, Kotenko I, Levorse J, DeCoste C, Schafer X, Lun Y, Lemischka IR. 2006. Dissecting selfrenewal in stem cells with RNA interference. Nature 442: $533-538$.

James D, Levine AJ, Besser D, Hemmati-Brivanlou A. 2005. TGF $\beta$ /activin/nodal signaling is necessary for the maintenance of pluripotency in human embryonic stem cells. Development 132: 1273-1282.

Jiang J, Chan YS, Loh YH, Cai J, Tong GQ, Lim CA, Robson P, Zhong S, Ng HH. 2008. A core Klf circuitry regulates self-renewal of embryonic stem cells. Nat Cell Biol 10: $353-360$.

Kelly KF, Ng DY, Jayakumaran G, Wood GA, Koide H, Doble BW. 2011. $\beta$-Catenin enhances Oct-4 activity and reinforces pluripotency through a TCF-independent mechanism. Cell Stem Cell 8: 214-227.

Kielman MF, Rindapaa M, Gaspar C, van Poppel N, Breukel C, van Leeuwen S, Taketo MM, Roberts S, Smits R, Fodde R. 2002. Apc modulates embryonic stem-cell differentiation by controlling the dosage of $\beta$-catenin signaling. Nat Genet 32: 594-605.

Kim J, Chu J, Shen X, Wang J, Orkin SH. 2008. An extended transcriptional network for pluripotency of embryonic stem cells. Cell 132: 1049-1061.

Kunath T, Saba-El-Leil MK, Almousailleakh M, Wray J, Meloche S, Smith A. 2007. FGF stimulation of the Erk1/2 signalling cascade triggers transition of pluripotent embryonic stem cells from self-renewal to lineage commitment. Development 134: 2895-2902.

Lawson KA, Pedersen RA. 1987. Cell fate, morphogenetic movement and population kinetics of embryonic endoderm at the time of germ layer formation in the mouse. Development 101: 627-652.

Lawson KA, Meneses JJ, Pedersen RA. 1991. Clonal analysis of epiblast fate during germ layer formation in the mouse embryo. Development 113: 891-911. 
B.J. Merrill

Lickert H, Cox B, Wehrle C, Taketo MM, Kemler R, Rossant J. 2005. Dissecting Wnt $/ \beta$-catenin signaling during gastrulation using RNA interference in mouse embryos. Development 132: 2599-2609.

Lindsley RC, Gill JG, Kyba M, Murphy TL, Murphy KM 2006. Canonical Wnt signaling is required for development of embryonic stem cell-derived mesoderm. Development 133: 3787-3796.

Loh YH, Wu Q, Chew JL, Vega VB, Zhang W, Chen X, Bourque G, George J, Leong B, Liu J, et al. 2006. The Oct4 and Nanog transcription network regulates pluripotency in mouse embryonic stem cells. Nat Genet 38: 431-440.

Lyashenko N, Winter M, Migliorini D, Biechele T, Moon RT, Hartmann C. 2011. Differential requirement for the dual functions of $\beta$-catenin in embryonic stem cell self-renewal and germ layer formation. Nat Cell Biol 13: 753-761.

Marikawa Y, Tamashiro DA, Fujita TC, Alarcon VB. 2011. Dual roles of Oct4 in the maintenance of mouse P19 embryonal carcinoma cells: As negative regulator of Wnt $/ \beta$-catenin signaling and competence provider for Brachyury induction. Stem Cells Dev 20: 621-633.

Marson A, Levine SS, Cole MF, Frampton GM, Brambrink T, Johnstone S, Guenther MG, Johnston WK, Wernig M, Newman J, et al. 2008. Connecting microRNA genes to the core transcriptional regulatory circuitry of embryonic stem cells. Cell 134: 521-533.

Martin GR. 1981. Isolation of a pluripotent cell line from early mouse embryos cultured in medium conditioned by teratocarcinoma stem cells. Proc Natl Acad Sci 78: $7634-7638$.

Matsuda T, Nakamura T, Nakao K, Arai T, Katsuki M, Heike T, Yokota T. 1999. STAT3 activation is sufficient to maintain an undifferentiated state of mouse embryonic stem cells. EMBO J 18: 4261-4269.

Mitsui K, Tokuzawa Y, Itoh H, Segawa K, Murakami M, Takahashi K, Maruyama M, Maeda M, Yamanaka S. 2003. The homeoprotein Nanog is required for maintenance of pluripotency in mouse epiblast and ES cells. Cell 113: 631-642.

$\mathrm{Ng} \mathrm{HH}$, Surani MA. 2011. The transcriptional and signalling networks of pluripotency. Nat Cell Biol 13: 490-496.

Nichols J, Evans EP, Smith AG. 1990. Establishment of germline-competent embryonic stem (ES) cells using differentiation inhibiting activity. Development 110: 13411348.

Nichols J, Zevnik B, Anastassiadis K, Niwa H, Klewe-Nebenius D, Chambers I, Scholer H, Smith A. 1998. Formation of pluripotent stem cells in the mammalian embryo depends on the POU transcription factor Oct4. Cell 95: 379-391.

Nichols J, Silva J, Roode M, Smith A. 2009. Suppression of Erk signalling promotes ground state pluripotency in the mouse embryo. Development 136: 3215-3222.

Nishiyama A, Xin L, Sharov AA, Thomas M, Mowrer G, Meyers E, Piao Y, Mehta S, Yee S, Nakatake Y, et al. 2009. Uncovering early response of gene regulatory networks in ESCs by systematic induction of transcription factors. Cell Stem Cell 5: 420-433.

Niwa H, Burdon T, Chambers I, Smith A. 1998. Self-renewal of pluripotent embryonic stem cells is mediated via activation of STAT3. Genes Dev 12: 2048-2060.
Niwa H, Miyazaki J, Smith AG. 2000. Quantitative expression of Oct-3/4 defines differentiation, dedifferentiation or self-renewal of ES cells. Nat Genet 24: 372-376.

Ogawa K, Nishinakamura R, Iwamatsu Y, Shimosato D, Niwa H. 2006. Synergistic action of Wnt and LIF in maintaining pluripotency of mouse ES cells. Biochem Biophys Res Commun 343: 159-166.

Otero JJ, Fu W, Kan L, Cuadra AE, Kessler JA. 2004. $\beta$ Catenin signaling is required for neural differentiation of embryonic stem cells. Development 131: 3545-3557.

Pereira L, Yi F, Merrill BJ. 2006. Repression of nanog gene transcription by Tcf3 limits embryonic stem cell self-renewal. Mol Cell Biol 26: 7479-7491.

Roose J, Molenaar M, Peterson J, Hurenkamp J, Brantjes H, Moerer P, van de Wetering M, Destree O, Clevers H. 1998. The Xenopus Wnt effector XTcf-3 interacts with Grouchorelated transcriptional repressors. Nature 395: 608-612.

Salomonis N, Schlieve CR, Pereira L, Wahlquist C, Colas A, Zambon AC, Vranizan K, Spindler MJ, Pico AR, Cline MS, et al. 2010. Alternative splicing regulates mouse embryonic stem cell pluripotency and differentiation. Proc Natl Acad Sci 107: 10514-10519.

Sato N, Meijer L, Skaltsounis L, Greengard P, Brivanlou AH. 2004. Maintenance of pluripotency in human and mouse embryonic stem cells through activation of Wnt signaling by a pharmacological GSK-3-specific inhibitor. Nat Med 10: $55-63$.

Schaniel C, Ang YS, Ratnakumar K, Cormier C, James T, Bernstein E, Lemischka IR, Paddison PJ. 2009. Smarccl/ Baf155 couples self-renewal gene repression with changes in chromatin structure in mouse embryonic stem cells. Stem Cells 27: 2979-2991.

Silva J, Barrandon O, Nichols J, Kawaguchi J, Theunissen TW, Smith A. 2008. Promotion of reprogramming to ground state pluripotency by signal inhibition. PLoS Biol 6: e253.

Smith AG, Heath JK, Donaldson DD, Wong GG, Moreau J, Stahl M, Rogers D. 1988. Inhibition of pluripotential embryonic stem cell differentiation by purified polypeptides. Nature 336: 688-690.

Takao Y, Yokota T, Koide H. 2007. $\beta$-Catenin up-regulates Nanog expression through interaction with Oct- $3 / 4$ in embryonic stem cells. Biochem Biophys Res Commun 353: 699-705.

Tam WL, Lim CY, Han J, Zhang J, Ang YS, Ng HH, Yang H, Lim B. 2008. T-cell factor 3 regulates embryonic stem cell pluripotency and self-renewal by the transcriptional control of multiple lineage pathways. Stem Cells 26: 20192031.

ten Berge D, Koole W, Fuerer C, Fish M, Eroglu E, Nusse R. 2008. Wnt signaling mediates self-organization and axis formation in embryoid bodies. Cell Stem Cell 3: 508-518.

Tesar PJ, Chenoweth JG, Brook FA, Davies TJ, Evans EP, Mack DL, Gardner RL, McKay RD. 2007. New cell lines from mouse epiblast share defining features with human embryonic stem cells. Nature 448: 196-199.

Thomson JA, Itskovitz-Eldor J, Shapiro SS, Waknitz MA, Swiergiel JJ, Marshall VS, Jones JM. 1998. Embryonic stem cell lines derived from human blastocysts. Science 282: $1145-1147$. 
Vallier L, Reynolds D, Pedersen RA. 2004. Nodal inhibits differentiation of human embryonic stem cells along the neuroectodermal default pathway. Dev Biol 275: 403-421.

Vallier L, Mendjan S, Brown S, Chng Z, Teo A, Smithers LE, Trotter MW, Cho CH, Martinez A, Rugg-Gunn P, et al. 2009. Activin/Nodal signalling maintains pluripotency by controlling Nanog expression. Development 136: 1339-1349.

Waddington CH. 1957. The strategy of genes. Geo Allen and Unwin, London.

Wagner RT, Xu X, Yi F, Merrill BJ, Cooney AJ. 2010. Canonical Wnt $/ \beta$-catenin regulation of liver receptor homolog1 mediates pluripotency gene expression. Stem Cells 28: 1794-1804.

Wang W, Lin C, Lu D, Ning Z, Cox T, Melvin D, Wang X, Bradley A, Liu P. 2008. Chromosomal transposition of PiggyBac in mouse embryonic stem cells. Proc Natl Acad Sci 105: 9290-9295.

Williams RL, Hilton DJ, Pease S, Willson TA, Stewart CL, Gearing DP, Wagner EF, Metcalf D, Nicola NA, Gough NM. 1988. Myeloid leukaemia inhibitory factor maintains the developmental potential of embryonic stem cells. Nature 336: 684-687.

Wray J, Kalkan T, Gomez-Lopez S, Eckardt D, Cook A, Kemler R, Smith A. 2011. Inhibition of glycogen synthase kinase- 3 alleviates Tcf3 repression of the pluripotency network and increases embryonic stem cell resistance to differentiation. Nat Cell Biol 13: 838-845.
Xu RH, Peck RM, Li DS, Feng X, Ludwig T, Thomson JA. 2005. Basic FGF and suppression of BMP signaling sustain undifferentiated proliferation of human ES cells. Nat Methods 2: 185-190.

Xu Y, Zhu X, Hahm HS, Wei W, Hao E, Hayek A, Ding S. 2010. Revealing a core signaling regulatory mechanism for pluripotent stem cell survival and self-renewal by small molecules. Proc Natl Acad Sci 107: 8129-8134.

Yi F, Merrill BJ. 2010. Non-cell-autonomous stimulation of stem cell proliferation following ablation of Tcf3. Exp Cell Res 316: 1050-1060.

Yi F, Pereira L, Merrill BJ. 2008. Tcf3 functions as a steady state limiter of transcriptional programs of mouse embryonic stem cell self renewal. Stem Cells 26: 1951-1960.

Yi F, Pereira L, Hoffman JA, Shy BR, Yuen CM, Liu DR, Merrill BJ. 2011. Opposing effects of Tcf3 and Tcf1 control Wnt stimulation of embryonic stem cell self-renewal. Nat Cell Biol 13: 762-770.

Ying QL, Nichols J, Chambers I, Smith A. 2003. BMP induction of Id proteins suppresses differentiation and sustains embryonic stem cell self-renewal in collaboration with STAT3. Cell 115: 281-292.

Ying QL, Wray J, Nichols J, Batlle-Morera L, Doble B, Woodgett J, Cohen P, Smith A. 2008. The ground state of embryonic stem cell self-renewal. Nature 453: 519-523.

Young RA. 2011. Control of the embryonic stem cell state. Cell 144: 940-954. 


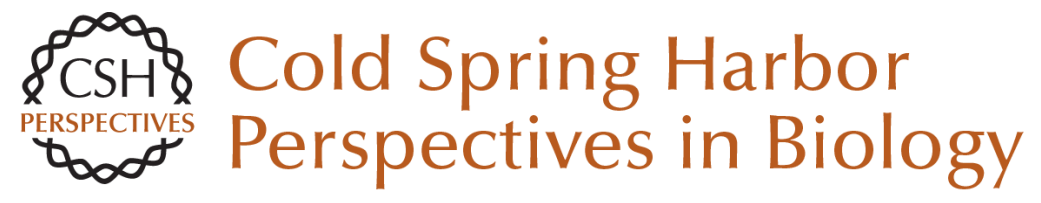

\section{Wnt Pathway Regulation of Embryonic Stem Cell Self-Renewal}

Bradley J. Merrill

Cold Spring Harb Perspect Biol 2012; doi: 10.1101/cshperspect.a007971

Subject Collection

For additional articles in this collection, see http://cshperspectives.cshlp.org/cgi/collection/

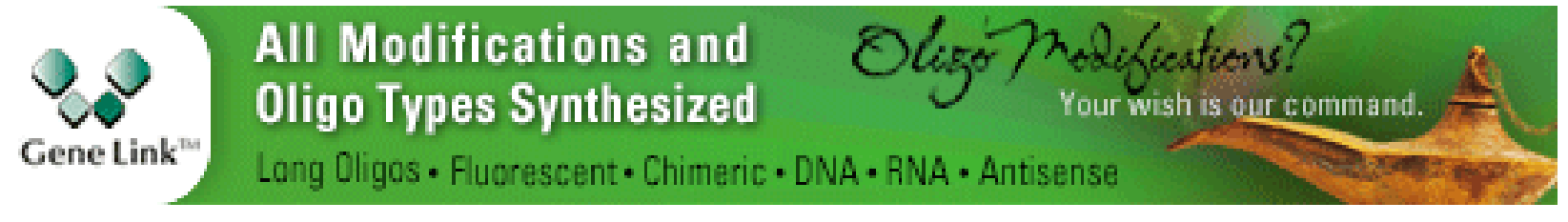

Copyright @ 2012 Cold Spring Harbor Laboratory Press; all rights reserved 